\title{
EDITORIAL
}

\section{POSSIVEIS FATORES RESPONSÁVEIS PELA MORTE INTRACELULAR DO PLASMÓDIO}

Em 1944 o casal Taliaferro observou a presença de formas degenerativas de plasmódio no interior de eritrócitos de primatas infectados com Plasmodium brasilianum e que foram interpretadas como devidas à morte intracelular do parasito 25 . O assunto só foi retomado 30 anos depois quando se verificou a ocorrência de formas semelhantes em camundongos tratados com fatores ativadores de macrófagos 23 . Sugeriu-se que a destruição intra-eritrocitária do plasmódio fosse devida a fatores séricos, não relacionados a anticorpos, porque: (a) ocorre precocemente, antes que anticorpos antiplasmódio possam ser detectados, (b) trofozoítos jovens são também afetados, quando se reconhece que, nesta fase, a membrana dos eritrócitos não é permeável a anticorpos e (c) os fatores séricos seriam produzidos por macrófagos ativados.

Vários fatores têm sido responsabilizados pela morte intracelular do plasmódio, entre eles, os radicais de oxigênio. Embora o produto final da redução do oxigênio seja a água, a redução parcial origina a formação de vários radicais intermediários, dotados de intensa atividade citotóxica: superoxido, peróxido de hidrogênio e hidroxila 18 . Estes radicais-produzidos por macrófagos e neutrófilos - apresentam atividade tóxica para diversos protozoários 21 . Algumas evidências indiretas sugerem que, durante sua fase intraeritrocitária, o plasmódio também poderia ser destruido por radicais de oxigênio: (1) a injeçào, em camundongos infectados, de compostos capazes de gerar radicais de oxigênio, como a aloxana ${ }^{5}$ ou o t-butilhidroperóxidol, causam reduçào significativa da parasitemia e aparecimento de formas degenerativas intra-eritrocitárias do plasmódio; (2) $P$. yoelii ${ }^{8}$ e $P$. falciparum ${ }^{30}$ são destruidos quando tratados in vitro com compostos que geram superóxido e peróxido de hidrogênio (este último seria o radical ativo já que o processo é revertido por adição de catalase); (3) o tratamento de eritrócitos parasitados por $P$. yoelii ou $P$. berghei in vitro com doses minimas de peróxido de hidrogênio interfere com a viabilidade dos parasitos 7 . Entretanto, estes dados foram obtidos a partir de situaçōes artificiais. A possivel ação de radicais de oxigênio sobre o plasmódio esbarra ainda em outras dificuldades. Existe uma importante diferença entre o processo de destruição intracelular do plasmódio e o que ocorre com outros protozoários. Tripanossomas,

\section{POSSIBLE FACTORS RESPONSIBLE FOR THE INTRACELLULAR DEATH OF PLASMODIA}

In 1944 the Taliaferro team observed the presence of degenerative forms of plasmodia inside erythrocytes of primates infected with plasmodium brasilianum, which they interpreted as due to the intracellular death of the parasite 25 . The subject was taken up 30 years later when similar forms were seen in mice treated with macrophage activating factors ${ }^{2} 3$. It was suggested that intraerythrocytic destructrion of plasmodia was the result of serum factors not related to antibodies because: (a) the event occurred before antiplasmodial antibodies could be detected; (b) young trophozoites were affected although the erythrocytic membrane is not permeable to antibodies at this stage and (c) the serum factors in question were produced by activated macrophages.

We still do not know the nature of these serum factors 23 but oxygen radicals have been suggested as possible mediators. Although the final product of oxygen reduction is water, partial reduction results in intermediate radicals with an intense cytotoxic activity such as superoxide, hydrogen peroxide and hydroxyl groups 18 . These radicals, produced by macrophages and neutrophils, show toxic activity for various protozoa 21 . Some indirect evidences suggest that, during their intraerythrocytic phase, plasmodia might be destroyed by such radicals: (1) In mice the injection of substances capable of producing oxygen radicals such as alloxan 5 or t-butyl-hydroperoxide ${ }^{1}$, cause the appearance of degenerating forms and a significant reduction in parasitaemia; (2) Plasmodium yoelii 8 and $P$. falciparum ${ }^{30}$ are destroyed when treated in vitro with substances which generate superoxide or hydrogen peroxide (this last radical seems to be the active radical since the process is reverted by addition of catalase); and (3) treatment of erythrocytes parasitised by $P$. yoelii in vitro with minimal doses of hydrogen peroxide interferes with the viability of the parasite 7 . However, all these data come from somewhat artificial situations. The possible effect of oxygen radicals on plasmodia raises other difficulties. There exists an important difference between the intracellular destruction process in plasmodia related to other protozoa. Trypanosomes, leishmania and toxoplasma infect macrophages and can be destroyed in the interior of these cells by oxygen radicals, but the intraerythrocytic destruction of plasmodia implies the secretion of toxic 
Editorial: Possiveis fatores responsáveis pela morte intracelular do plasmódio. Carlos Eduardo Tosta. Revista da Sociedade Brasileira de Medicina Tropical 17: 55-58, Abr-Jun, 1984

leishmanias e toxoplasma infectam macrófagos e, no seu interior, podem ser destruidos por radicais de oxigênio. Já a destruição intra-eritrocitária do plasmódio implica na secreção de produtos tóxicos por macrófagos ativados e sua posterior ação sobre o parasito no interior do eritrócito. De fato, o plasmódio ativa macrófagos tanto in vitro ${ }^{19}$ quanto in vivo $28 \mathrm{e}$ estes, em conseqüencia, podem secretar radicais de oxigènio 17. A ação de tais radicais tóxicos só se manifestaria nas áreas de maior gradiente, proximas às células que produzissem, já que eles possuem meiavida extremamente curta12. Entretanto, formas degenerativas de $P$. falciparum podem ser induzidas com soros de indivíduos imunes, previamente depletados de $\operatorname{IgG}^{16}$. Além do mais, no interior dos eritrócitos, o peróxido de hidrogênio e os radicais superóxido sofreriam a ação inibidora da catalase ${ }^{13}$ e da superóxido dismutase ${ }^{6}$, respectivamente. Note-se que também o plasmódio possui superóxido dismutase ${ }^{10}$, o que explicaria niveis aumentados desta enzima nos eritrócitos parasitados 24 e concorreria para protegê-lo da ação lesiva dos radicais de oxigênio. Tais observações têm estimulado a investigação de fatores alternativos para explicar a destruição intracelular do plasmódio.

Demonstrou-se que camundongos tratados com fatores ativadores de macrófagos e, posteriormente injetados com endotoxina, passam a apresentar em seu soro atividade tóxica para células tumorais, imputadas a um "fator de necrose tumoral". Esta atividade foi detectada no soro de camundongos inoculados $\operatorname{com} P$. vinckei, 2 horas aṕos a injeção de endotoxina ${ }^{4} \mathrm{e}$ tambèm em infecções por outra: espécies de plasmódio de roedores 2627 e infecção humana 30 . Entretanto, tal fator - recentemente identificado como linfotoxina ${ }^{31}$... ainda não foi isolado e caracterizado quimicamente e a situação em que ele é produzido é bastante artificial, exigindo a injeção prévia de endotoxina.

Interferon é outro produto de macrófagos ativados capaz de exibir atividade citotóxica. Niveis elevados de interferon sérico têm sido demonstrados em camundongos infectados 14 , enquanto que indutores de interferon exibem efeito protetor contra a infecção ${ }^{15}$. Nas infecções humanas os resultados são menos claros: a elevação dos niveis séricos foi demonstrada por um grupo ${ }^{9}$ mas nào por outro 22 , enquanto que interferon alfa foi incapaz de induzir formas degenerativas de P. falciparum in vitro ${ }^{16}$.

A enzima poliamino-oxidase constitui outro potencial mediador da morte intracelular do plasmódio. Produzida por macrófagos ativados, cataliza a products by activated macrophages, which subsequently acts on the parasite dwelling in the erythrocyte. Plasmodia activate macrophages both in vitro 19 and in vivo 28 and could stimulate oxygen radical secretion, but these toxic substances act maximally near the cells producing them and they possess a very short half life 12 . However, degenerative forms of $P$. falciparum can be induced in cultures treated with the serum of immune individuals, previously depleted of $\mathrm{IgG}^{16}$. Also, in the interior of erythrocytes, hydrogen peroxide and superoxide radicals suffer an inhibitory reaction from catalase ${ }^{13}$ and superoxide dismutase 6 respectively. Furthermore plasmodia possess superoxide dismutase ${ }^{10}$ which explains the high levels of this enzyme in parasitised erythrocytes ${ }^{24}$. This has a protector function against free oxygen radicals. These observations have stimulated the investigation of alternative factors to explain intracellular death of plasmodia.

It has been shown that mice treated with macrophage activating factors and later injected with endotoxin may present in their sera a toxic activity for tumour cells, the so called "tumour necrosis factor". This activity was detected in the sera of mice infected with $P$. vickei, 2 hours after the injection of endotoxin ${ }^{4}$ and also in infections with rodent plasmodial species 2627 and in human infections ${ }^{30}$. The factorrecently identified as a lymphotoxin 31 - has yet to be isolated and chemically characterised. It is produced in artificial situations where endotoxin has to be injected previously.

Interferon is another product of activated macrophages and exibits cytotoxic activity. Elevated levels of serum interferon have been demonstrated in infected mice ${ }^{14}$ and interferon inducers show a protective effect against infections ${ }^{15}$. In human infections the results are less clear: a rise in serum levels was demonstrated by one group ${ }^{9}$ but not by another 22 . Interferon was not able to induce degeneration of P. falciparum trophozoites in vitro 16 .

The enzyme polyamino-oxidase is another potential mediator of plasmodial death in cells. Produced by activated macrophages, it catalyses the deamination of the polyamines spermine and spermidine encountered in sera, originating toxic radicals including those of oxygen ${ }^{20}$. The incubation of erythrocytes parasitised by $P$. falciparum with a mixture of polyamine oxidase and spermine, but not with each one alone, induces a decrease in the viability of plasmodia and the appearance of degenerative forms 1123 . Although the mechanism of action of polyamino-oxidase is still not 
desaminação das poliaminas espermina e espermidina encontradas no soro, originando produtos tóxicos, inclusive radicais de oxigênio 20 . A incubação de eritrócitos parasitados por $\boldsymbol{P}$. falciparum com uma mistura de poliamino-oxidase e espermina, mas não com cada uma isoladamente, induz diminuição da viabilidade do plasmódio e o aparecimento de formas degenerativas 1123 . Embora o mecanismo de ação da poliamino-oxidase não tenha ainda sido esclarecido, os dados já obtidos sugerem a participação de aldeidos e de acroleína, originados da oxidação da poliamina, ao invés de radicais tóxicos de oxigênio, também formados pelo processo.

A diversidade de dados sugere que, provavelmente mais de um mecanismo deve estar envolvido na morte intracelular do plasmódio. De fato, formas degenerativas do parasito sāo observadas tanto em pacientes submetidos à quimioterapia como em culturas, quando as condições de meio são inadequadas. Em um aspecto, entretanto, os diversos dados disponíveis são concordes: macrófagos ativados produzem fatores tóxicos para o plasmódio. Evidência morfológica foi obtida através do exame à microscópia eletrônica do baço de camundongos infectados com P. berghei 29 e de primatas com P. knowlesi ( $\mathrm{CE}$ Tosta, G Ruiz, N Wedderburn: dados não publicados): eritrócitos e plasmódio, acumulados na periferia da polpa branca por efeito da estase, apresentam alterações ultra-estruturais, tanto mais intensas quanto mais próximas as células se encontram de macrófagos ativados.

Um melhor conhecimento sobre a natureza dos mediadores da morte intracelular do plasmódio, além de permitir melhor entender os mecanismos de defesa do hospedeiro, poderá contribuir decisivamente para o desenvolvimento de uma nova familia de agentes quimioterápicos com função orientada no sentido de estimular a formação de produtos tóxicos para o plasmódio.

\section{REFERÊNCIAS BIBLIOGRÁFICAS}

1. Allison AC, Eugui E. A radical interpretation of immunity to malaria parasites. The Lancet 2: 14311433,1982 .

2. Clark IA. Resistance to Babesia spp. and Plasmodium sp. in mice pretreated with an extract of Coxiella burnetti. Infection \& Immunity 24: 319-325, 1979 . :

3. Clark IA, Cox FEG, Allison AC. Protection of mice against Babesia spp. and Plasmodium spp. with killed Corynebacterium parvum. Parasitology 74: 9-18, 1977. clarified the data obtained suggest the participation of aldehydes and acrolein, originated from the oxidation of polyamine, rather than toxic oxygen radicals, also formed during the process.

Probably the diversity of the data suggests that more than one mechanism is involved in intracellular death of plasmodia. In fact, degenerative forms of the parasites are observed both in patients submitted to chemotherapy as well as in cultures when the conditions of the media are inadequate. It does appear from the evidence available that macrophages produce toxic factors against plasmodia. In $P$. berghei infections ultrastructural alterations of parasites in the spleen appeared to be more intense in those in proximity to activated macrophages 29 . Similar observations are available for the Plasmodium knowlesi model in monkeys (CE Tosta, G Ruiz, N Wedderburn: unpublished observations).

Investigations on the nature of the mediators of intracellular death of plasmodia will contribute to a better knowledge of the mechanisms involved in defence against malaria and may permit the development of a new family of drugs capable to stimulate the production of toxic mediators for plasmodia.

4. Clark IA, Virelizier JL, Carswell EA, Wood PR. Possible importance of macrophage-derived mediators in acute malaria. Infection \& Immunity 32: 1058-1066, 1981.

5. Clark IA, Hunt NH. Evidence for reactive oxygen intermediate causing hemolysis and parasite death. Infection \& Immunity 39: 1-6, 1983.

6. Concetti A, Massei G, Rotilio M, Brunori M, Rachmilewitz EA. Superoxide dismutase in red blood cells: method of assay and enzyme content in normal subjects and in patients with beta - thalassemia (major and intermedia). Journal of Laboratory and Clinical Medicine 87: 1057-1064, 1976.

7. Dockrell HM, Playfair JH. Killing of blood - stage murine malaria parasites by hydrogen peroxide. Infection \& Immunity 39: 456-459, 1983.

8. Dockrell HM, Playfair JH. Killing of Plasmodium yoelii by enzyme - induced products of the oxidative burst. Infection \& Immunity 43: 451-456, 1984.

9. Druilhe P, Rhodes-Feuilette A, Canivet M, Gentilini M, Periès J. Circulating interferon in patients with Plasmodium falciparum, $P$. ovale and $P$. vivax malaria. Tran- 
Editorial: Possiveis fatores responsáveis pela morte intracelular do plasmódio. Carlos Eduardo Tosta. Revista da Sociedade Brasileira de Medicina Tropical 17: 55-58, Abr-Jun, 1984

sactions of the Royal Society of Tropical Medicine and Hygiene 76: 422-423, 1982.

10. Fairfield AS, Meshnick SR, Eaton JW. Malaria parasites adopt host cell superoxide dismutase. Science 221 : 764-766, 1983.

11. Ferrante A, Rzepczyk CM, Allison AC. Polyamine oxidase mediates intra-erythrocytic death of Plasmodium falciparum. Transactions of the Royal Society of Tropical Medicine and Hygiene 77: 789-791, 1983

12. Fridovich I. Oxygen: boon and bane. American Scientist 63: 54-59, 1975.

13. Hartz JW, Funakoshi S, Deutsch HF. The levels of superoxide dismutase and catalase in human tissues as determined immunochemically. Clinica Chimica Acta 46: $125-132,1973$.

14. Huang KY, Schultz WW, Gordon FB. Interferon induced by Plasmodium berghei. Science 162: 123-124, 1968.

15. Jahiel RI, Nussenzweig RS, Vanderberg J, Vilcek J. Anti-malarial effect of interferon inducers at different stages of development of Plasmodium berghei in the mouse. Nature 220: 710-711, 1968.

16. Jensen JB, Boland MT, Allan JS, Carlin JM, Vande Waa JA, Divo AA, Akood MAS. Association between human serum - induced crisis forms in cultured Plasmodium falciparum and clinical immunity to malaria in Sudan. Infection \& Immunity 41: 1302-1311, 1983.

17. Johnston RB Jr, Godzik CA, Cohn ZA. Increase of superoxide anion production by immunologically activated and chemically elicited macrophages. Journal of $\mathrm{Ex}^{-}$ perimental Medicine 148: 115-127, 1978.

18. Klebanoff SJ. Oxygen metabolism and the toxic properties of phagocytes. Annals of Internal Medicine 93: $480-489,1980$

19. Makimura S, Brinkman V, Mossmann H, Fischer H Chemiluminescence response of peritoneal macrophages to parasitized erythrocytes and lysed erythrocytes from Plasmodium berghei - infected mice. Infection \& Immunity 37: 800-804, 1982.

20. Morgan DML, Christensen JR, Allison AC. Polyamine oxidase and the the killing of intracellular parasites. Biochemical Society Transactions 9: 563-564, 1981.
21. Nathan CF. Mechanisms of macrophage antimicrobial activity. Transactions of the Royal Society of Tropical Medicine and Hygiene 77: 620-630, 1983.

22. Rytel MW, Rose HD, Steward RD. Absence of circulating interferon in patients with malaria and with American trypanosomiasis. Proceedings of the Society for Experimental Biology and Medicine 144: 122-123, 1973.

23. Rzepczyk CM, Saul AJ, Ferrante A. Polyamine oxidase - mediated intraerythrocytic killing of Plasmodium falciparum: evidence against the role of reactive oxygen metabolites. Infection \& Immunity 43: 238-244, 1984.

24. Suthipark U, Krungkrai J, Jearnpipatkul A, Yuthavong $Y$, Panijpan B. Superoxide dismutase (SOD) in mouse red blood cells infected with Plasmodium berghei. Journal of Parasitology 68: 337-339, 1982.

25. Taliaferro WM, Taliaferro LG. The effect of immunity on the ase xual reproduction of Plasmodium brasilianum. Journal of Infectious Diseases 75: 1-32, 1944.

26. Taverne J, Dockrell HM, Playfair JHL. Endotoxin induced serum factor kills malarial parasites in vitro. Infection \& Immunity 33: 83-89, 1981.

27. Taverne J, Depledge P, Playfair JHL. Differential sensitivity in vivo of lethal and nonlethal malarial parasites to endotoxin - induced serum factor. Infection \& Immunity 37: 927-934, 1982.

28. Tosta CE, Ruiz G, Wedderburn N. Effects of lethal and non-lethal malaria on the mononuclear phagocyte system. Revista da Sociedade Brasileira de Medicina Tropical 16: 58-67, 1983.

29. Tosta CE, Ruiz G, Wedderburn N. The role of spleen macrophage in malaria: an ultrastructural study. Revista da Sociedade Brasileira de Medicina Tropical 17: 31-36, 1984.

30. Wozencraft AO, Dockrell HM, Taverne J, Targett GA, Playfair JH. Killing of human malaria parasites by macrophage secretory products. Infection \& Immunity 43: $664-669,1984$

31. Zacharchuk CM, Drysdale BE, Mayer MM, Shin HS. Macrophage - mediated cytotoxicity: role of a soluble macrophage cytotoxic factor similar to lymphotoxin and tumor necrosis factor. Proceeding of the National Academy of Sciences USA 80: 6341-6345, 1983.

Carlos Eduardo Tosta

Laboratório de Imunologia Celular

Faculdade de Ciências da Saúde

Universidade de Brasilia

70910 Brasilia, DF. 